$9-1-2006$

\title{
For What May We Hope? Thoughts on the Eschatological Imagination
}

John E. Thiel

Fairfield University, jethiel@fairfield.edu

Follow this and additional works at: https://digitalcommons.fairfield.edu/religiousstudies-facultypubs

\section{Peer Reviewed}

\section{Repository Citation}

Thiel, John E., "For What May We Hope? Thoughts on the Eschatological Imagination" (2006). Religious

Studies Faculty Publications. 43.

https://digitalcommons.fairfield.edu/religiousstudies-facultypubs/43

\section{Published Citation}

Thiel, John E. "For What May We Hope? Thoughts on the Eschatological Imagination." Theological Studies 67.3 (2006): 517-541.

This item has been accepted for inclusion in DigitalCommons@Fairfield by an authorized administrator of DigitalCommons@Fairfield. It is brought to you by DigitalCommons@Fairfield with permission from the rightsholder(s) and is protected by copyright and/or related rights. You are free to use this item in any way that is permitted by the copyright and related rights legislation that applies to your use. For other uses, you need to obtain permission from the rights-holder(s) directly, unless additional rights are indicated by a Creative Commons license in the record and/or on the work itself. For more information, please contact digitalcommons@fairfield.edu. 


\title{
FOR WHAT MAY WE HOPE? THOUGHTS ON THE ESCHATOLOGICAL IMAGINATION
}

\author{
JOHN E. THIEL
}

\begin{abstract}
After reflecting on the reluctance of modern theology to engage in eschatological speculation, the author argues that plenty of traditional Catholic beliefs warrant a rich exercise of the eschatological imagination. The life of the blessed dead provides a test case for such speculation, with Jesus' own resurrected life in the Gospels invoked as an interpretive measure for the resurrected life of believers.
\end{abstract}

$\mathrm{N}^{\mathrm{s}}$ EAR THE END of the Critique of Pure Reason (1781), Kant took stock of his philosophical project by observing that all the interests of speculative and practical reason come together in three questions: "What can I know?" "What ought I to do?" "What may I hope?"1 Kant had already addressed and answered the first question earlier in the work, and in a way that undermined the very possibility of traditional metaphysics: I may know worldly appearances presented in the manifold of sense experience as ordered by the a priori categories of the understanding. There is no knowledge, he claimed, without sensibility shaped by the intellect. The second question would be addressed and answered in the Critique of Practical Reason (1788): I ought to act on the basis of the moral imperative constructed a priori by practical reason.

Although addressed in the First and Second Critiques, the third question was not itself the subject of a book-length writing, undoubtedly because it functioned only as a heuristic for the second question. I may hope for a final happiness in God and a future life beyond death: "two postulates which, according to the principles of pure reason, are inseparable from the

John E. Thiel earned his Ph.D. in religious studies from McMaster University, Hamilton, Ontario, and is currently professor of religious studies and director of the University Honors Program at Fairfield University, Connecticut. Specializing in fundamental and systematic theology, he has recently published Senses of Tradition: Continuity and Development in Catholic Faith (Oxford University, 2000) and God, Evil, and Innocent Suffering: A Theological Reflection (Crossroad, 2002). He is at work on a monograph on eschatology.

${ }^{1}$ Immanuel Kant, Critique of Pure Reason, trans. N. K. Smith (New York: St. Martin's Press, 1965) 635 (B833 in the 2nd ed.). 
[moral] obligation which that same [practical] reason imposes on us."2 God and life after death are hypotheses required by pure practical reason to ensure that morality finally will be its own reward, even if happiness proves elusive in this life. Hope in this Kantian key is dispassionate. It is not the emotional companion of an ardent faith. As mere postulates, the objects of Kantian hope do not evoke ardor, and hope, for Kant, is not the sister of faith, as Charles Péguy suggested. ${ }^{3}$ Rather, Kantian hope in the life to come is only a guiding principle that offers the possibility of rational consistency and purposiveness to one's moral life here and now.

It is with some irony that I have chosen a variant of Kant's well-known question for the title of a paper on the eschatological imagination. As his answer to the third question attests, Kant had no eschatological imagination. Kant would not have been offended by this judgment. For him, the faculty of imagination is incapable of eschatological employment since it requires the concreteness of sensibility to go about its business, and God and the afterlife are not possible objects of sensible experience. In the short essay that Kant did devote to eschatology, he makes this point clearly: "The speculative man [sic] becomes entangled in mysticism where his reason does not understand itself and what it wants, and rather prefers to dote on the beyond than to confine itself within the bounds of this world, as is fitting for an intellectual inhabitant of a sensible world; for reason, because it is not easily satisfied with its immanent, that is, its practical use but likes to attempt something in the transcendent, also has its mysteries." 4 And these mysteries, Kant continues, are the pseudo-concepts of "eternal repose" served up by the various religions, concepts "in company with which ... understanding disintegrates and all thinking itself comes to an end." 5

It is both expected and surprising that modern theologians have followed Kant's lead in their attention to eschatology. On the one hand, Kant's position on the limitations of knowledge has become axiomatic in modern theories of interpretation. Embraced theologically, it issues in the expected refusal of theologians to speak flourishingly about the afterlife. On the other hand, this epistemological modesty is somewhat surprising when one recalls that assertions about the afterlife are not claims for knowledge but claims made in faith. It is surprising that many modern theologians have chosen to observe the Kantian strictures on knowledge, since the understanding they construct is measured (or should be!) by faith in the Christ

2 Ibid. 639 (839 in the 2 nd ed.).

${ }^{3}$ Charles Péguy, The Portal of the Mystery of Hope, trans. D. Schindler, Jr. (Grand Rapids, Mich.: Eerdmanns, 1996).

${ }^{4}$ Immanuel Kant, "The End of All Things," in On History, ed. Lewis White Beck, trans. Robert E. Anchor and Emil L. Fackenheim (Indianapolis: BobbsMerrill, 1963) 79.

${ }^{5}$ Ibid. 
event as revealed in Scripture and tradition. The apologetic interests of modern theologians do much to explain this anomaly. Concerned to justify their discipline before the canons of critical thinking, many theologians have been willing to embrace historicist assumptions in order to play by the same epistemic rules as fellow travelers in the academy. Or, better put, apologetic theologians make some interpretive negotiation between the value of critical knowing and the claims of revelation, since, they assume, neither can be consistently reconciled with the other on its own terms.

This negotiation is more accomplishable for theological loci that address Christian realities within the scope of history. A theology of tradition or a theology of the church or a theological anthropology all interpret a possible object of experience, even if the claim be made that the sensible object has a supernatural orientation. Eschatology will have a much more difficult time satisfying apologetic interests. The "last things" are not possible objects of sensible experience but instead are objects of a hope inextricably tied to faith. For believers, the last things are not mere postulates but realities and events having to do with the very meaning of life and the final destiny of the human person. The subject matter of eschatology, then, explains the paucity of modern writing on this topic compared to other theological issues. And even when theologians address this topic, it is interesting to see how much their work transpires as though Kant were looking over their shoulders. Abiding by Kant's own critical strictures, theologians who write today on eschatology often explore the existential dimensions of Christian hoping, and are decidedly reluctant to speculate on the objects of hope professed in faith. Eschatology then becomes a kind of "immanentology" in which talk about the life to come is really taken to be talk about life in the present.

In opposition to this view, I will argue that theology should not be resigned to the Kantian despair of the eschatological imagination. Theology on this side of the Enlightenment need not be embarrassed by metaphorical accounts of the afterlife, for such accounts can be powerful expressions of faith and hope. I will begin by illustrating the modern assumption of proper restraint on the eschatological imagination in the work of Karl Rahner, proceed by proposing a traditional justification for a more speculative approach to eschatology, and conclude by considering how a richer use of the eschatological imagination might be theologically warranted and religiously edifying. Any number of topics that fall under the rubric of eschatology could be enlisted to illustrate these points. In these pages, I will focus on the topic of resurrected life.

\section{ON GETTING IT HALF RIGHT: RAHNER ON ESCHATOLOGICAL ASSERTIONS}

A good example of the modern restraint on the eschatological imagination can be found in the writings of Karl Rahner, especially in his pro- 
grammatic essay, "The Hermeneutics of Eschatological Assertions." ${ }^{6}$ Here Rahner insists on the need for a special hermeneutics for understanding eschatological beliefs, a need that seems to be prompted by typically Kantian assumptions regarding the limitations of knowledge. "The idea that such [a special] hermeneutics has been sufficiently catered for by hermeneutics in general," Rahner observes, "rests on the false and primitive conception, that the eschata form a world like any other, so that knowledge of them-in spite of its being determined, like other knowledge, by the object itself-presents no particular problems apart from those of the knowledge of theological realities in general." ${ }^{77}$ Eschatology requires a special hermeneutics precisely because the objects of its knowledge are unavailable, and unavailable in a way that encourages error in their interpretation. Rahner reminds his reader that eschatology is about the real future that is God's, a future that lies beyond the control of human knowledge or action. God knows the future omnisciently, but God's future is also finitely knowable in principle by human persons, since human destiny is a crucial dimension of that future. Yet, acknowledging that God's future may be humanly knowable does not mean that God's future can be known in fine detail by human beings now, within the scope of history. Even though God could reveal everything of the end-time to humanity, God has not. Moreover, it would be erroneous to think that scriptural accounts of the end are "pre-views of future events." 8 Such a view reduces the engaged believer to a disinterested voyeur who makes God's future "only what is yet to come from a distance, and no longer that which is at hand in its futurity."

A meaningful eschatology, Rahner argues, is one in which knowledge of the future emerges from the existential circumstances of the believer's life now. The future "is an inner moment of man [sic] and of his actual being as it is present to him now. And so knowledge of the future, in so far as it is still to come, is an inner moment in the self-understanding of man in his present hour of existence-and grows out of it." ${ }^{10}$ Eschatology must recognize the appropriate limitations on knowledge. Vain presumption beckons the interpreter beyond those limits to conjure apocalyptic in the false forms of "phantasy or gnosticism." Eschatology, then, has cause for modesty in its account of God's future, which in and of itself cannot be completely known, at least under the epistemic conditions of history. Eschatology must speak strictly out of the present moment as the knowable way in which God's future is encountered in the life of faith. "By and in being

${ }^{6}$ Karl Rahner, "The Hermeneutics of Eschatological Assertions," in Theological Investigations, vol. 4, trans. Kevin Smyth (Baltimore, Md.: Helicon, 1966) 323-46.

7 Ibid. 324.

${ }^{9}$ Ibid. 329.

8 Ibid. 328.

${ }^{11}$ Ibid. 337.

${ }^{10}$ Ibid. 331. 
oriented toward the future," Rahner claims, "[the human person] must know about his future. But in such a way, that this knowledge of the future can be a moment in his knowledge of the present. And only thus."12

This last phrase-“"And only thus"-voices Rahner's caution against extending eschatological assertions beyond their properly existential scope of meaning. The concerns of modern epistemology stir this caution, but so too does a particular understanding of God. Throughout his writings, Rahner delights in portraying God as holy mystery, as a wellspring of loving grace whose eternal depths defy comprehension even as they evoke the desire for meaning in human life. As the "Whither of transcendental experience," God remains "the nameless, the indefinable, the unattainable,"13 the infinite mystery within which human persons discover and actualize the horizon of their own finite mystery. The eschata are the fulfillment of the human quest for God. As elements of divine knowledge, they lie hidden in God's being. But more, as divinely willed and gracefully achieved human destiny, the eschata are a dimension of the mystery of God's own being and, as such, share in the infinite mystery within which human persons encounter the "more" of finite transcendence. For Rahner, the eschata are mysterious both for epistemological reasons and for ontological reasons. Human knowledge cannot help but fall short of divine being because human knowledge is limited, and divine being is not. Since the eschata share in the divine mystery, they defy speculative description on these two related counts.

A good application of this position-at once Kantian and theologicalcan be found in another of Rahner's writings on eschatology. "The Life of the Dead." Here Rahner argues that the persistent courage of human transcendence in the face of life's seemingly insurmountable obstacles illustrates the presence of eternity in time. Eternal life grows out of the present moment as human freedom responds to death productively, raising death from empty destruction to a radical limit before which persons become fully themselves in choosing God. Death is only meaningful as deep loss, Rahner insists, when human life has become something to lose. And only a human life that has already entered eternity here and now by knowingly or unknowingly embracing God's future is worthy of death's meaningful loss. "It is only because we have become immortal in our life," Rahner states, "that death with its menacing and impenetrable mask of destructivity is for us so deadly."14 Eternal life can only be spoken of meaningfully as the life of the living, since we are separated from the dead by the rupture of death.

12 Ibid. 332.

${ }^{13}$ Karl Rahner, "The Concept of Mystery in Catholic Theology," in ibid. 50.

${ }^{14}$ Karl Rahner, "The Life of the Dead," in ibid. 349. 
Even though eternity can be encountered within our personal histories, the eternal life of the dead, Rahner claims, eludes our conceptual and imaginative grasp. While the living "are still creatures in time," the dead dwell in the mystery of "absolute nearness to God." ${ }^{15}$ Living within the life of God, the dead transcend the scope of our actual experience, and of their encounter with eternity, Rahner frankly admits, "there is not much we can say." Faith enables us to say at least that the mystery into which the dead have gone is one of "unspeakable bliss." Yet, "the sheer silence of [this] bliss cannot be heard by our ears." certainly reflects Rahner's Kantian sensibilities. Yet, as I have argued, these Kantian sensibilities complement his Ignatian mysticism and, so mingled, emerge in a theology of God as inexhaustible mystery, a mystery into which Rahner enfolds the life of the dead. It should be no surprise, then, that Rahner extends the same apophatic regard for the divine mystery to the blessed dead dwelling in the divine life. Just as imagination and expression are utterly humbled before the task of representing God, so too are these temporally bound powers humbled before the prospect of representing the blessed dead, inaccessible as they are in the mysterious life of God. This dual apophasis, Rahner concludes, directs us to seek what we may experience of eternity only existentially in the present moment, where silence, and not speech, is the appropriate response: "we meet the living dead, even when they are those who are loved by us, in faith, hope and love, that is, when we open our hearts to the silent calm of God himself, in which they live; not by calling them back to where we are, but by descending into the silent eternity of our own hearts, and through faith in the risen Lord, creating in time the eternity which they have brought forth forever." 17

Rahner's eschatological modesty is not an unusual stance in the trajectory of modern theology. Both Protestant and Catholic kinds of liberal theology are governed by Kantian assumptions on the limitations of knowledge, which require that one speaks of the last things immanently, if one speaks of them at all. ${ }^{18}$ The same might be said for Reformed theology in a Barthian style, which is happy to employ Kantian epistemology to warrant a classical Reformation understanding of divine otherness and the distance of the dead. ${ }^{19}$ But even if Rahner's position is generally illustrative of the modern deferral to Kantian sensibilities, it is especially interesting in

15 Ibid. 353, 352.

17 Ibid. 353-54.

18 There are many examples. A good one is: Kathryn Tanner, Jesus, Humanity and the Trinity: A Brief Systematic Theology (Minneapolis: Fortress, 2001) 97-124.

${ }^{19}$ Barth makes this point nicely in his discussion of heaven in the Church Dogmatics: "Heaven is the boundary which is clearly and distinctly marked off for man [sic]. It exists. But in distinction from earth it exists as invisible creaturely reality. 
the way it advances those sensibilities through a theological understanding of God as mystery. As the heading to this section of my article announces, I am unconvinced by Rahner's argument in toto, though I am willing to concede the validity of one of his two principal points. Explaining this criticism will introduce the constructive portion of this article.

Rahner is certainly correct in his view that experience and talk of the eschata grow out of the present moment and "only thus" may the eschata be represented theologically. Although this stance possesses a Kantian resonance in the modern period, it is difficult to deny that it is something of a truism throughout the entire Christian tradition, if not in theory then at least in practice. Aquinas and Kant hold remarkably different assumptions about reality. And yet both would maintain that the workings of imagination and understanding require the raw material of sense data, as does the speech that brings them to expression. Both agree that sensibility provides realistic content to our mental operations, even though they explain the formal contributions of subjectivity to the construction of knowledge in different ways. Indeed, one of Rahner's signal contributions to modern theology is his retrieval of this Thomistic teaching on the indispensability of sensibility for representation in light of the Kantian critique of traditional metaphysics. ${ }^{20}$ Rahner's retrieval demonstrates the real consistency throughout the premodern and modern periods on the issue of theological representation, namely, that ideation and expression require the contributions of sensibility as the representable. It is no wonder, then, that Rahner discusses eschatology only out of the experience of the present moment, which includes, of course, the existentially-present past and the existentially-present future. Hermeneutical modesty about the eschata itself would require such a stance, were it not for the even stronger warrant that an alternative position could not be palpably imagined.

Although Rahner rightly regards the present moment as a proper base for thought and speech about the eschata, there is no reason in principle that this safeguard against fantastic speculation need result in the theological conclusions he reaches about the life of the dead. Rahner complements his position on the need for an existential eschatology by enfolding the dead in the divine mystery. This constructive stance in turn justifies his hermeneutics of eschatological statements. If the dead dwell within the

It is invisible and therefore incomprehensible and inaccessible, outside the limits of human capacity. ... It is not merely God who is incomprehensible; the same can also be said of heaven within the creaturely world" (Karl Barth, Church Dogmatics, 4 vols. in 12, ed. G. W. Bromiley, trans. G. W. Bromiley and Harold Knight [Edinburgh: T. \& T. Clark, 1960] 3, part 3:424-25).

${ }^{20}$ The classical locus is Karl Rahner, Spirit in the World, trans. William Dych (London: Sheed and Ward, 1968). 
divine mystery, then, like the divine mystery, they transcend the concrete particulars of thought and expression. Faith affirms the sheer bliss enjoyed by the blessed dead within the divine life, but the character of that state of blessedness is as indescribable as the divine mystery that both causes and occludes this bliss. Hermeneutical modesty before the eschata is appropriate, Rahner thus claims, for two, mutually supportive reasons. First, responsible theological construction must respect the limitations on knowledge set by the sensible conditions of representation. Although Rahner invokes this epistemological principle theologically, its Kantian resonance applies more generally to any form of speculation ventured by reason or imagination. Second, the nature of the blessed dead, engulfed as they are in God, demands that these epistemological strictures be respected for an explicitly theological reason that bolsters the cause of hermeneutical modesty. Rahner extends the proper apophatic regard of faith for the divine mystery to the blessed dead as well, making silence the most apt theological response to the state of blessedness. The dead are distant from the present moment. And even though the present moment might be eschatologically constructed in meaningful ways, the afterlife is not capable of meaningful description. The kind of eternal life enjoyed by the distant dead, lost as they are in God's own mysterious being, constrains the eschatological imagination to the point of mystical silence.

It is this second half of Rahner's double-sided position that I do not think is correct. For Rahner, the critical judgment that eschatology should respect the legitimate boundaries of knowledge issues in a theological position on the life of the dead that follows the Kantian rule on hermeneutical modesty. ${ }^{21}$ While there is good reason for a modern theology like Rahner's to respect the Kantian rule, there is no reason that the epistemological principles informing the rule need shape the representation of the blessed dead in the way they do in his theology. Indeed, I will argue that the relationships between and among several basic Catholic doctrines encourage the theologian to say much more about the life of the dead than Rahner is willing to say, even though he insists that it is proper to speak about the eschata in and through the present historical moment. While Rahner finds both epistemological consistency and theological profundity in what I would call his "thin" eschatology, I will argue that hermeneutical

${ }^{21}$ I would be willing to concede that there may be no direct connection between Rahner's regard for the Kantian rule and his constructive position on the life of the dead. It may be that the consistency between the two positions is simply a matter of coincidence, that his theological construction of the life of the dead is not the consequence of his epistemological assumptions, and that I have committed the logical error of post hoc ergo propter hoc. But if that were so, it would seem to imply Rahner's own inconsistency in applying his special hermeneutics of eschatological assertions. 
modesty does not require this approach, and that a "thick" eschatologyone that exercises the eschatological imagination more rigorously-can be much more effective in portraying "the assurance of things hoped for, the conviction of things not seen" (Heb 11:1).

\section{IDOLATRY AND SACRAMENTALITY}

Modern theology has been reluctant to engage the eschatological imagination for several reasons. The Kantian critique of metaphysics is one. Another reason, quite frankly, is the fear that any detailed account of the afterlife would simply be vulgar. This fear is not exclusively a modern concern. The Gospel writers were reluctant to describe the afterlife in any detail, even when they recounted what they received as Jesus' own words. The parables of Jesus consistently eschew a literal description of heavenly life, offering instead evocative images of the Kingdom of God that stir the human hope for fulfillment. Even though Paul claimed to have an ecstatic vision of paradise, he refused to describe it (2 Cor 12:2-4), justifying his silence by the sacredness of what he saw and, in an earlier letter, offering the believing community the same evocation of hope that the Gospel writers would: "no eye has seen, nor ear heard, nor the human heart conceived, what God has prepared for those who love him" (1 Cor 2:9). The Book of Revelation may seem to be an exception to this biblical reticence. A close scrutiny of the text, however, finds no description of the afterlife. The apocalyptic events it details occur in this life and not in the next. That these historical occurrences are portrayed through highly symbolic language seems to be John's indirect judgment that a literal description of the endtime too would be vulgar and unworthy of the religious imagination.

The New Testament silence on the afterlife tacitly condemns any sensibility that diminishes the scope of fulfillment to the familiar, and, as a consequence, undermines the hope that faith evinces. But there is another, much more pernicious, kind of vulgarity that seems to be at work in both the ancient and modern constraints on the eschatological imagination, namely, the idolatry that traditionally has been understood as the root of moral evil. Christian salvation is so bound up with the mystery of God's divine life that any imaginative account of the afterlife seems to entail a literal description of God, as though images of the afterlife would force the reduction of God to an image of human making. Since idolatry is traditionally understood as the preeminent $\sin$ (Gen 3:5; Exod 20:4-6), heavenly description could be counted the work of invidious arrogance much more than the folly of epistemological excess. The age-old practice of negative theology, iconoclastic sensibilities, and the Kantian strictures on speculative theology all in their own ways bespeak the same concern for idolatry in too lavish an exercise of the eschatological imagination. 
Sinful corruption, however, presupposes corruptible goodness, and here, in what Christian belief regards as the sacramental character of creaturely reality, one finds theological license for the eschatological imagination. The opening scene in Genesis affirms the goodness of creation, and sees creaturely goodness as a reflection of the Creator's own unbounded goodness. Medieval theology offers a thicker description of this creaturely virtue by speaking of the transcendental qualities of being, which, like God, is not only good but also one, true, and beautiful. The doctrine of the Incarnation consummates the doctrine of creation in the belief that creaturely reality is so good and redeemable that the divine nature could embrace it in the humanity of the Savior, and in the saving participation of that humanity in the resurrection of Jesus. Christian belief in the sacraments as means of grace confirms the capacity of finite existence to mediate the infinitely divine, a belief powerfully professed in the Catholic doctrine of the real presence of Christ in the Eucharist. Idolatry is an ever-present concern in theological representation, to say nothing of Christian life, because it moves in the same trajectory as authentic sacramentality, appealing to the same finitude of being as a communication of the divine, but now in a way that limits the divine to the given and circumscribable. Idolatry is reductive sacramentality, a constriction that ironically becomes a transgression of the proper terms of relationship between the divine and the creaturely. ${ }^{22}$ But prior to this reduction, in the created conditions of reality, lies a resource for eschatology that, though fallen, is both good and redeemed, and which might be put to good theological use.

Having made the point that a fuller exercise of the eschatological imagination need not be idolatrous in principle, I hasten to make another. If eschatological representation is guilty of idolatry, it may be so in one of two ways. Eschatology always concerns the reality of God and the divine actions that bring about the eschata. An eschatology could be idolatrous by identifying God and God's eschatological actions with the creaturely. Idolatry of this sort is risked in all theological inquiry, as humanly limited concepts and language try as they might to grasp the infinite. But this kind of idolatry is perniciously accomplished in chiliasm - the literal reduction of God's actions to the events of history. Chiliasm is not a pressing theological problem in our time, although, as a warrant for ideological violence, it has increasingly become a political problem. As was noted earlier, mod-

${ }^{22}$ This understanding of idolatry as a perversion of sacramentality is suggested in the work of Marion and Chauvet. See Jean-Luc Marion, God without Being: Horstexte, trans. Thomas A. Carlson (Chicago: University of Chicago, 1991) 163-69; Louis-Marie Chauvet, Symbol and Sacrament: A Sacramental Interpretation of Christian Existence, trans. Patrick Madigan, S.J., and Madeleine E. Beaumont (Collegeville, Minn.: Liturgical, 1995) 216-20. 
ern theologians have been reluctant to engage the eschatological imagination, and so have not been seduced by this sort of idolatry.

A second kind of eschatological idolatry would move in the opposite direction by elevating the creature in the afterlife to divine proportions. In one version of this excess, the creaturely contours of the blessed dead would be lost in an unqualified mystical union with God as God. Now, it is questionable whether there are actual examples of this kind of idolatry in the theological tradition, which, unlike the concrete chiliasm of the first kind of eschatological idolatry, would take the form of a spiritualized gnosticism. Meister Eckhart has been accused of this kind of theological failure, an accusation magnified by his willingness to include the living as well as the dead in mystical union with God. Leaving aside the legitimacy of this charge, we need only note that Eckhart's style of mysticism is extraordinarily rare in the tradition, particularly when it is advanced as normative Christian faith and not as the heterodox criticism of it. ${ }^{23}$ The Eastern Christian tradition of representing the life of the blessed dead as a state of divinization is another example of mystical sensibilities pressed far. But this traditional conception of salvation has proven its orthodox status over the centuries by refusing to dissolve creatureliness into an unqualified union with God.

Given the paucity of idolatrous representations of the creaturely dead as God, we can conclude that the modern reluctance to represent the blessed dead is not virtuous avoidance of a seductive theological temptation. Indeed, the fear of this kind of idolatry seems to be stirred by a category mistake. Concerns about idolatry in the representation of the blessed dead derive from the false conflation of the afterlife with the divine being itself, and so the utterly erroneous assumption that a description of the afterlife would entail a reductive description of God. The biblical account of creation and the ancient Christian creeds speak of heaven as a created reality, and thus distinguishable from God even as the divine abode. Christian belief maintains that creatures do not lose their creatureliness in the afterlife. Speaking of the blessed dead cannot be equated with speaking about God, as much as God is gracefully implicated in any talk of the blessed dead. This point becomes even more important for the possibilities of the

${ }^{23}$ Steven Ozment's helpful distinction between a Latin or christocentric mysticism and a Germanic or theocentric mysticism in late medieval Christianity highlights the prevalence of the former and the virtual identification of the latter category with Eckhart. See Steven Ozment, The Age of Reform 1250-1550: An Intellectual and Religious History of Late Medieval and Reformation Europe (New Haven: Yale University, 1980) 115-16. Cyril O'Regan's unfolding scholarly project explores the heterodox-critical varieties of gnosticism. See Cyril O'Regan, Gnostic Return in Modernity (Albany, N.Y.: SUNY, 2001) and Gnostic Apocalypse: Jacob Boehme's Haunted Narrative (Albany, N.Y.: SUNY, 2002). 
eschatological imagination when one recalls that traditional Christian hope yearns for an embodied salvation. Whether the ancient metaphysical categories of body and soul or modern psychological categories of physical and emotional relationship are invoked to convey the reality of the human person, a Christian understanding of resurrected life insists on the holistic integrity of the saved self, and so properly rejects the notion of the real loss of the blessed dead in God. Like any dimension of authentic sacramentality, the created integrity of the blessed dead could be idolatrously corrupted by their false identification with God. Examples of this kind of sin in the tradition, though, seem to be rare indeed, if they exist at all.

Another way of making this same point, and in a way that highlights the irony at work in modern theological practice, is that our very efforts to avoid idolatry themselves give rise to idolatry. Our theological avoidance of talk about the eschata intends to honor the distance between the divine and the human. And yet, that very gesture itself succumbs to the idolatrous assumption that the proximity of the blessed dead to God warrants their regard through an apophatic lens properly reserved for God. Our good theological intentions fail by making too much of the blessed dead and so, by consequence, too little of God, and all in the name of rigorous theological method or mystical profundity.

When all is said and done, the modern reluctance to represent the blessed dead issues as much from Reformation sensibilities about authentic sacramentality as it does from Kantian sensibilities about the limits of knowledge. The Reformers vehemently attacked the Catholic belief in and practice of the cult of the saints, since it implicated all the neuralgic points of dispute among 16th-century Christians. The Reformers saw idolatry in Catholic veneration of the saints, judging saintly patronage in the afterlife to usurp the mediating role of Christ as Savior. In the view of the Reformers, the saints in heaven valorized the religious actions of ascetics from whom their ranks were drawn. The blessed dead exercised a sacred agency that compromised the very strong doctrine of grace at the heart of Reformation spirituality. Reformation faith thus embraced the notion of the blessed dead as distant from the living. In the afterlife, they were enfolded into the predestinating will of God by which they were chosen from all eternity. The afterlife of the saints was unimaginable because only the activity of the blessed dead is seriously imaginable, and, in the Reformation reading of Paul, human activity has no graceful integrity of its own.

This last point may serve as a transition to the next step in our argument. If Reformation and Kantian sensibilities have mutually configured modern assumptions about the eschatological imagination, then Catholic sensibilities need to adjudicate the extent to which these concerns are appropriate to its task. Modern Catholic theology rightly has learned much from Kant about the limits of knowledge and the excesses of traditional metaphysical 
speculation. But Catholic theology should be wary of granting final epistemic authority to philosophical strictures that would have disallowed the great artistic, poetic, and theological exercises of the religious imagination throughout the Catholic tradition. The unity of that tradition suggests that the scandal of an excluded past would make for an equally scandalous present or future. And even though Kantian epistemology nicely supports Protestant sensibilities on the unavailability of the blessed dead, there is no reason at all for Catholic theology to relinquish its peculiar style of Christian sensibility to embrace a style not its own, however typical that style may now be. The challenging task for a Catholic theology is not just to imagine the blessed dead, but more importantly to imagine the blessed dead in ways that are faithful to the mainstays of Catholic belief and in ways that may serve as icons of hope for believers. It is to that task that we now turn.

\section{WHAT DOES JESUS DO IN THE AFTERLIFE?}

Caroline Walker Bynum has observed that to "twentieth-century nonChristians and Christians alike, no tenet of Christianity has seemed more improbable-indeed, incredible - than the doctrine of the resurrection of the body." 24 Anyone who knows the rich ways that bodily resurrection animated the faith of premodern believers cannot help but be struck by its absence in contemporary Christian belief. When contemporary Christians imagine the afterlife, they tend to do so dualistically, as the continuance of a disembodied soul. Thinking in the manner of ancient Platonists. they assume that the fullness of the self resides in its invisible dimensions, beyond the fluctuations of the body that eventually are rife with old age, disease, and death. The creed, however, professes belief in the resurrection of the body and so insists on an afterlife in which the entire person is saved. Ancient Christians not only believed in bodily resurrection but also went to great lengths to imagine how it would occur and how it would perdure, as their art and theological speculation testify. ${ }^{25}$ The resurrected Jesus was a paradigm for their religious imaginings, and we would do well to follow their time-honored example by making the resurrected Jesus a paradigm for imagining the life of the blessed dead in the pages to follow.

Paul's discussion of the afterlife in 1 Corinthians 15 is the earliest Christian testimony to Jesus' resurrection as a model for the resurrection of

${ }^{24}$ Caroline Walker Bynum, "Material Continuity, Personal Survival, and the Resurrection of the Body: A Scholastic Discussion in its Medieval and Modern Contexts," in Fragmentation and Redemption: Essays on Gender and the Human Body in Medieval Religion (New York: Zone, 1991) 239.

${ }^{25}$ See Carolyn Walker Bynum, The Resurrection of the Body in Western Christianity, 200-1336 (New York: Columbia University, 1995). 
believers. For Paul, the denial of the resurrection of the dead on the part of the new Corinthian converts amounted to a denial of Jesus' resurrection, since, Paul infers, the resurrection of Jesus is the graceful source and cause of resurrection itself (1 Cor 15:12-19). Yet, Jesus' resurrection remains in the background of Paul's concerns as he tries to sketch a holistic account of the believer's resurrected life. The narrative commitments of the later evangelists put the resurrected Jesus in full view of the believer as a paradigm for imagining the afterlife. In its original form, the Gospel of Mark portrays the resurrection of Jesus only in the powerful image of the empty tomb. The resurrected Jesus makes no appearance (Mk 16:1-8), as he does in the longer ending and in the later Gospels. Matthew includes two appearance scenes-to the women leaving the tomb and to the disciples in the closing passage-that offer little detail of Jesus' new resurrected life (Mt 28:9-10, 16-20). Luke and John make much of post-Easter appearances, writing elaborately of Jesus' resurrected life. As different as their accounts of the post-Easter Jesus are, these Gospel writers share some common understandings of the appearances, and these similarities can inform our project.

It is a commonplace in the interpretation of the later resurrection appearances to highlight the issue of Jesus' identity, and to do so by stressing the reality of Jesus' resurrected body. Both Luke and John acknowledge that Jesus' resurrected body is different from his body before Easter. His resurrected body is not easily recognized, as demonstrated in Luke's story of the disciples on the road to Emmaus (Lk 24:13-32) and John's story of Mary Magdalene mistaking the resurrected Jesus for the gardener (Jn 20:11-16). His body appears or disappears miraculously, and so is not subject to the ordinary conditions of finite existence (Lk 24:31, 36, 51; Jn 20:19, 26). The Evangelists make the very same point about the resurrected Jesus that Paul had made about resurrected" life decades earlier-that the body in resurrection transcends the limitations of the body in death ( 1 Cor 15:42-44). And yet, while acknowledging the saved and saving difference in the person of the resurrected Lord, both Luke and John are especially intent on showing that this Jesus is the same person who was born and lived and died on the cross. Both do so by having the resurrected Jesus make his wounded body the proof of his identity. The Lucan account has Jesus say to his startled disciples before whom he has appeared: "'Look at my hands and my feet; see that it is I myself. Touch me and see; for a ghost does not have flesh and bones as you see that I have"' (Lk 24:39). In one of the most compelling scenes in all the Gospels, John has the disciple Thomas make the crucifixion wounds the proof of Jesus' resurrected identity, and Jesus is happy to oblige when he appears to him (Jn 20:24-29).

Interpretive attention to Jesus' embodied identity in the resurrection is an important corrective to the dualistic understandings of afterlife that 
prevail in contemporary Christian communities. If Jesus' afterlife is normative for the afterlife of believers, then the New Testament narratives insist on the indispensability of embodiment for identity, and so for the saved identity of the blessed dead. And yet, this close relationship between identity and embodiment can occlude other aspects of Jesus' resurrected identity that are just as crucial for the eschatological imagination. Embodiment, after all, can be conceived statically, as a state of being conveyed by the mere fact of physicality. There is a sense in which Jesus' demonstrative use of his body as a marker of continuous identity in Luke and John encourages such a view. Considered in this way, embodiment is a quality of identity as inert as a metaphysical essence. I propose that we broaden the scope of Jesus' resurrected identity by attending to his embodied actions in the appearance scenes. These actions, Jesus' "doing" in his resurrected life, can enliven our imagination about the life of the blessed dead.

What does Jesus do in his resurrected life? According to both the Apostles' Creed and the Nicene Creed, Jesus is "seated at the right hand of the Father" and he "will come again" to judge the living and the dead. ${ }^{26}$ A literal reading of the ancient professions of faith seems to suggest that the resurrected Jesus is inactive, waiting until the end of time to continue his saving work as the Son of God. Luke and John imagine things differently. Even though these Gospels together offer precious few pages on the resurrected life of the risen Lord, they do consistently present the identity of Jesus through his actions. The richness of Scripture, its own fecund sacramentality, offers many possible descriptions of such actions. ${ }^{27}$ I would like to focus on the following: the way that Jesus keeps his promises, bears the pain of his life without reproach, reconciles failure, and shows himself to be who he is.

Fulfillment is the most obvious theme that runs through the resurrection accounts. The Gospel writers narrate the resurrection of Jesus as they do to proclaim the truth that all lives, all of creation, and all of history have been fulfilled in the Easter event. All four Gospels express this fulfillment through the image of the empty tomb, and the Synoptic Gospels bring this image to clear articulation in the announcement of the resurrection by

${ }^{26}$ Enchiridion symbolorum, definitionum, et declarationum de rebus fidei et morum, ed. Henricus Denzinger and Adolfus Schönmetzer, S.J. (Freiburg im Briesgau: Herder, 1967) nos. 30, 150.

${ }^{27}$ On the sacramentality of Scripture, see Chauvet, Symbol and Sacrament 21327. One might object that the resurrection appearances of Jesus in the Gospels are themselves exercises of the theological imagination and so are poor warrants for the theological speculation offered here on the life of the blessed dead. I agree that the appearance stories in Scripture are acts of theological imagination in narrative form. Yet, their canonical status authorizes these imaginative acts as God's inspired word. Imagination and authority need not be disjunctively posed in the life of faith. 
heavenly messengers. We should note, though, that this fulfillment is something that Jesus does, not only in the eventfulness of the resurrection itself but also in the way that this event is his keeping of a promise. Mark's Gospel makes this point most clearly. Mark presents the resurrection of Jesus as a dramatic surprise after the seemingly hopeless tragedy of Jesus' tortuous death. Yet, Mark expects that surprise will be transformed into purpose as readers recall the crucial scene at the center of the Gospel in which Jesus' identity is under discussion. In response to Jesus' question, "'But who do you say that I am?"” (Mk 8:29), Peter declares that Jesus is the Messiah. This response prompts Jesus to explain what being the Messiah means: "Then he began to teach them that the Son of Man must undergo great suffering. and be rejected by the elders, the chief priests, and the scribes, and be killed, and after three days rise again" (Mk 8:31). Even though this passage characterizes Jesus' explanation as instruction, the Easter event seems to raise it to the heights of promise, and, in light of the Easter event, to the summit of a promise fulfilled.

Promises are the most important words that persons speak, since they extend personal relationship into an unseen future in which faithfulness may be broken. A promise bespeaks constancy of character. It verbalizes the speaker's most serious intention to be a committed self beyond the present moment. A promise kept is the fulfillment of personal character as it stands in relation to others, and that fulfillment is achieved in the struggles that keeping a meaningful promise entails. If we consider Jesus in resurrection as someone who has kept his promise to be the risen Lord, then this is a promise that he has made to be most fully himself by facing the trial of torture and death so that, through his resurrection from the dead, God could destroy death for all. ${ }^{28}$

The role of the crucifixion in the fulfillment of Jesus' promise to save the world brings us to another of his activities in the afterlife. The resurrected Jesus bears the pain of his life without reproach. This forbearance is not simply resurrection behavior but extends from Good Friday to Easter and beyond. Jesus remains an innocent victim throughout his false indictment, his torture, and his terrible execution. And though innocent, he refuses to reproach the many agents of imperial power who enact its violence. In resurrection, Jesus continues to act in this way. He calls attention to his wounds in order to stir the resurrection faith of his disciples. But he does not lay blame for their infliction, either historically by mention of Roman

${ }^{28}$ I have developed this theological motif at length in my God, Evil, and Innocent Suffering: A Theological Reflection (New York: Crossroad, 2002). This same motif is developed from another angle in James Alison, Raising Abel: The Recovery of the Eschatological Imagination (New York: Crossroad, 1996). 
violence or the betrayal of a friend, or theologically by mention of sinful humankind.

Jesus' disposition in this regard offers an interesting contrast to Job's in the face of his innocent suffering. In order to make the innocence of Job's suffering utterly clear, the book's author leaves no doubt in the opening scene that it is God, and not Job, who bears responsibility for all the evil that suddenly befalls the just man (Job 1-2). Job voices his innocence with like clarity. His eloquent speeches lament the terrible injustice that has been done to him. He reproaches God for what he rightly believes is God's guilt, and he reproaches his friends for their pious defenses of God and their easy willingness to blame the victim. In noting this difference between Jesus and Job, I do not mean to suggest that Job's response is inappropriate. Job's lament is courageously prophetic. Railing against the injustice of his suffering, he speaks righteously on behalf of any faithful believer beset by undeserved suffering. His words attempt to end the violence that has entered his life by naming its cause. Jesus, of course, is no stranger to prophetic speech of this sort. In scene after Gospel scene he speaks against the power of evil at work in the world, and especially against its effects in the lives of the marginalized. Jesus, though, does not raise his voice to protest or to blame with regard to his own suffering, either before or after the resurrection. In the afterlife, Jesus' wounds identify who he is, but they are not his evidence for the injustice done to him or for the guilt of the perpetrators. Jesus' unwillingness to reproach his offenders defines a higher standard of moral response that achieves an eschatological clarity in his resurrected life, when the irreversible evil done to him cannot be checked by lament, and reproach would only perpetuate the reciprocity of blame that makes new victims. Job himself may approach this higher standard in his final silence before God (Job 42:1-6).

Another activity of the resurrected Jesus is his reconciliation of failure. The Gospels consistently agree that Jesus died alone. Jesus and his message may have inspired discipleship in the later years of his life, but the specter of the cross led his disciples to flee in the face of danger and worldly judgment. Scripture scholars often point out that the disciples' abandonment of Jesus is such a scandal for the early church that its acknowledgment in all four Gospels is strong evidence of its historicity. Certainly this most bitter of injustices, at the hands of friends and not strangers, must be counted first among those that Jesus does not reproach. In spite of this terrible offense, the resurrected Jesus both forgives failure and carries his forgiveness to the point of reconciliation. The best example of this relentless forgiveness appears in Jesus' reconciliation of Peter in John's Gospel. In the Gospel's closing scene, Jesus asks Simon Peter three times if he loves him, and three times Peter affirms his love. With each affirmation, Jesus presses Peter into the commitment that he lacked the night before Jesus 
died, when Peter, fearing his own arrest, three times denied his association with Jesus. The resurrected Jesus does the work of reconciliation not only by the symmetry of his forgiveness but also by entrusting Peter with responsibility for the nascent church. With every confession of Peter's love, Jesus urges his care toward the faithful with the words, "Feed my lambs," "Tend my sheep," "Feed my sheep" (Jn 21:15-17). It is Jesus who allows Peter to mend their broken relationship, and it is Jesus who strengthens their renewed friendship by a remarkable act of faith in their future together. Having denied Jesus and, by so doing, having participated in the breaking of his body, Peter now is charged with the task of nurturing the body of Christ in the world. ${ }^{29}$

The final activity of the resurrected Jesus that I would like to consider is the way he shows himself to be who he is. In his important book The Identity of Jesus Christ, Hans Frei makes the interesting observation that Jesus is most himself in his resurrection. ${ }^{30}$ This claim seems rather strange to a time in which the question of Jesus' identity is typically answered by yet another scholarly reconstruction of the historical Jesus. Frei approaches the identity of Jesus in quite a different way by attending to Jesus' character, his integrity as a person. Jesus' character cannot be described on the basis of historical evidence, for such evidence is lacking and, even more, holds little interest for faith. A believer's regard for the person of Jesus has all the evidence it needs in the biblical narrative where Jesus' character takes shape in the events of his life, death, and resurrection.

In describing Jesus' character, Frei resists the modern inclination to think of identity as a function of subjectivity. Personal identity, he argues, does not well up in inner feelings but takes shape as one's intentions are consistently brought to action in the course of life. This rather un-Romantic and empirical approach to identity might seem more compatible with the historian's rational regard for Jesus up to the point of his death. To the contrary, Frei maintains that the Gospels portray Jesus not simply as a person who said and did things from birth to death, but as a person whose words and deeds are consummated in his resurrection from the dead. As Frei puts it: "To know who he is in connection with what took place is to know that he is. This is the climax of the story and its claim. What the accounts are saying, in effect, is that the being and identity of Jesus in the resurrection are such that his nonresurrection becomes inconceivable." ${ }^{31}$ The resurrection is not an event that functions as a kind of "add-on" to

${ }^{29}$ Rowan Williams makes this same scene the cornerstone for his reflections on the meaning of forgiveness in the light of Jesus' resurrection. See Rowan Williams, Resurrection: Interpreting the Easter Gospel (Cleveland: Pilgrim, 2002) 23-44.

${ }^{30}$ Hans W. Frei, The Identity of Jesus Christ: The Hermeneutical Bases of Dogmatic Theology (Philadelphia: Fortress, 1975) 139-52.

${ }^{31}$ Ibid. 145. 
Jesus' life, even one in which he becomes extrinsically "more" than he was prior to his resurrection. For Frei, the resurrection is the event that provides unity to all that Jesus said and did, such that Jesus becomes most fully who he is precisely in his resurrection from the dead. By the same token, we can say that all that Jesus says and does in his afterlife stands in continuity with his preceding character-forming words and deeds.

Frei makes a wonderful observation here that describes exactly how believers encounter Jesus' graceful presence, itself a function of who he is believed to be, namely, the risen Lord. This last activity of the resurrected Jesus-that he shows himself to be who he is-is actually a more general account of the other activities that we have already considered, all of which manifest Jesus' identity by demonstrating his character in action. It would be interesting to consider whether and how Frei's observation about the resurrected Jesus applies to believers in ways that can allow us to speculate meaningfully about their own resurrected life.

\section{JESUS' RESURRECTED LIFE AND OURS}

Jesus' resurrected life is interesting in its own right, as everything about him is. Our interest in his eschatological deeds, though, has been prompted by what they might mean for the resurrected life of believers. The Christian belief that our common humanity shares in Jesus' resurrected life justifies this comparison, as does the way that Jesus' actions set the standard for Christian discipleship. And yet, whatever homologies between Jesus and believers justify our comparison, there are important differences to consider. First and foremost, Jesus is the Savior, the divine Son of God, and so is exceptional in every respect, including his resurrection. Jesus' resurrection is not the received gift of eternal life, as is ours, but the gift itself, the event that redeems the world. Moreover, Jesus' bodily resurrection occurs three days after his death. In Christian belief, the bodily resurrection of believers does not occur until the last judgment. ${ }^{32}$ Until that event, the disembodied souls of the blessed dead experience the fulfillment of heavenly life. This difference between Jesus' resurrection and our own means that we cannot speak literally of the embodied actions of believers in resurrected life until the miracle of bodily resurrection has taken place.

It is important to note, however, that the tradition has affirmed a real consistency in the life of the blessed dead before and after the eschato-

${ }^{32}$ With respect to modern theological interpretation of this belief, I agree with Josef Ratzinger, who resists all attempts to interpret bodily resurrection as an event that occurs individually and immediately upon death. See Joseph Ratzinger, Eschatology, Death, and Eternal Life, trans. Michael Waldstein (Washington: Catholic University of America, 1988) 241-60. 
logical union of body and soul. This is expressed most clearly in the fourteenth-century teaching of Benedict XII. Condemning the theological views of his predecessor John XXII, Benedict taught that the disembodied soul in heavenly bliss enjoys the fullness of the beatific vision, and that the resurrected union of soul and body after the last judgment adds nothing to this experience. John held the view that bodily resurrection was required for the beatific vision to occur at all, since the metaphysical integrity of the person dwells in the union of body and soul. John thus imagined a heavenly wait for the soul in a diminished afterlife before the resurrection, deprived of the beatific vision. The purport of Benedict's authoritative teaching was that saved persons do not experience varying degrees of heavenly bliss throughout their lives in blessedness. The resurrection adds nothing to the redeemed encounter with God in the beatific vision. ${ }^{33}$ It is interesting to notice that the same religious concerns motivated both sides in this disagreement. The integrity of the saved person mattered to both John and Benedict, the former finding it in the unity of the soul and body and the latter in the unity of undiminished, heavenly joy. In this controversy, as in everyday life, the immediate satisfaction of longing trumped metaphysical consistency.

Benedict's teaching affirms that, before God, the self remains wholly itself, even when the effects of deathly fragmentation linger into the afterlife in the separation of soul and body. His position is not that the body does not matter, for Christian sensibilities demand that it does. Rather, he maintains that the unity of the self-same person-in soul and body-is never lost in the presence of God. This unity of the saved self before and after bodily resurrection provides a traditional warrant for speaking of the activity of the blessed dead as embodied even before the general resurrection, if not exactly then at least by inference drawn from our eschatological destiny. This proleptic warrant enables us to transcend the difference between Jesus' afterlife and the afterlife of believers prior to resurrection, and in such a way that Jesus' afterlife can be paradigmatic for thinking about the blessed dead on this side of the eschaton. ${ }^{34}$ Let us consider, then,

${ }^{33}$ For a good summary of this controversy, see Bynum, The Resurrection of the Body 283-91.

${ }^{34}$ In an effort to resist the modern and postmodern reduction of the body to a biological factum, Anthony Godzieba proposes the application of the medieval "four senses" of scripture to the body. Here I am proposing something akin to his "anagogic sense" of the body: "God's promise for our embodied selves made manifest in the glorified body of the Lord" (Anthony J. Godzieba, "Bodies and Persons, Resurrected and Postmodern: Towards a Relational Eschatology," in Theology and Conversation: Towards a Relational Theology, ed. J. Haers and P. De Mey [Dudley, Mass.: Peeters, 2003] 220). Like Godzieba, I want to respect the tradition's meaningful distinction between body and soul in accounting for the 
the embodied actions of the resurrected Jesus as a heuristic for thinking about resurrected life.

What might it mean for the blessed dead to imitate the way that Jesus keeps his promises in resurrected life? The promise that served as our earlier example was nothing less than Jesus' divine promise to save the world. For creatures, of course, this promise is inimitable since there is no respect in which they can make or keep it. In the case of the blessed dead, we must consider the eschatological fulfillment of promises made at the creaturely level.

One way of considering the realm of human sinfulness is as a tragic collection of broken promises. This conceptualization has its roots in the Jewish covenant, which is a set of promissory relationships between God and the people of Israel, between God and individual human persons, and among human persons. To keep these promissory relationships is to live in faithfulness to God and one's neighbor. To break them is to sin. The brokenness of sinful lives is nothing other than the brokenness of promises to be faithful in relationship. This is not to say that every promise we make must be kept in order to be faithful to God, our neighbor, and ourselves. As Margaret Farley has demonstrated, many of our promises are conditional, and changes in time and circumstance may require their redefinition or even their responsible dissolution. ${ }^{35}$ As a moral rule, though, the inability to keep a promise represents sinful failure, whether the promise is explicit or tacitly defined by the expectations of personal relationship. For all but the extraordinary saints, death marks the loss of worldly opportunity to keep unkept promises or to mend relationships severed by sinful betrayal.

If we imagine the task of discipleship extending into the afterlife, then perhaps we can think of the blessed dead as engaged in the moral task of promise-keeping. This engagement can be like Jesus' embodied action to the extent that the blessed dead continue to be faithful to promises they have kept in their earthly lives. Promise-keeping becomes transformative imitation of Jesus when the promises broken in the course of earthly life are renewed and faithfully kept eschatologically. To imagine the blessed dead as active in this way is to imagine them engaged in overcoming sin, particularly sin of their own making. Or, to express the same idea from another angle, to imagine the blessed dead active in this way is to imagine them at work in securing the ties of moral relationship. Since moral relationship takes shape in a communal setting, there is no reason for us to

integrity of the self, while not being constrained by a false literalism on either side of the distinction.

${ }^{35}$ Margaret A. Farley, Personal Commitments: Beginning, Keeping, Changing (San Francisco: Harper \& Row, 1986). 
conceive this activity in a dyadic fashion, as though love, friendship, or commitment flourish only between two personal partners, or to conceive relationship as transpiring only between the blessed dead. The Catholic notion of the communion of the saints assumes that the living and the dead are bound together in a network of relationships as the one body of Christ, even if we are too accustomed to think of the moral life of the Church triumphant as quiescent. And if Martin Buber's existentialist analysis of personal relationship can be instructive for thinking about the communion of the saints, then no personal relationship in this world or the next transpires without itself sharing in, and being gracefully nourished by, personal relationship with God. ${ }^{36}$

The advantage to this focus on promise-keeping is that it enables us to imagine the communion of the saints as an activity in which the blessed dead participate by imitating Jesus' resurrected life. We can observe this as well in the second kind of embodied action on the part of the resurrected Jesus. We noticed that Jesus bears the pain of his life without reproach. He refuses to indict those whose sin has brought him to suffering and death. Even though prophetic speech indicts the injustice of sin and can be extraordinarily virtuous, there is something especially inspiring about Jesus' unwillingness to blame or even to speak at all of the causes of his suffering. A high Christology might explain Jesus' silence as his self-assured confidence in a saving plan scripted from all eternity. Since the events of cross and resurrection have destroyed the power of suffering, there is no reason for the resurrected Jesus to credit the causes of suffering at all by speaking of their power in his life. His silence bespeaks his victory. A better explanation would attend to Jesus' character as demonstrated by his consistent actions. In this perspective, Jesus' achievement as a person lies in his willingness to forgive those who have done him harm. Jesus is very explicit in offering words of forgiveness in the Gospel of Luke as he hangs dying on the cross (Lk 23:34). Attending Jesus' articulate act of forgiveness is the striking silence of his unwillingness to reproach those who have done him harm. Jesus' refusal to blame should be understood as a behavioral precondition for his forgiveness of both strangers and friends, and thus as an indispensable dimension of this astounding act of forgiveness itself.

It is interesting to notice how closely the ancient creeds join the eschatological events of "forgiveness of sins" and "resurrection of the body." As tempting as it may be to understand the forgiveness of sins exclusively as an act of God that saves the forgiven, a fuller appreciation would include

${ }^{36}$ Martin Buber, I and Thou, trans. Ronald Gregor Smith (New York: MacMillan, 1987) 6, 75. David Kelsey insightfully employs the motif of promise-keeping for imagining redemption in David $\mathbf{H}$. Kelsey, Imagining Redemption (Louisville: Westminster John Knox, 2005) 21-41. Kelsey's focus is on the graceful encounter with Jesus' redemptive power in this life. 
the responsibility of believers to forgive those who have done them harm, as expected in the only prayer that Jesus taught his disciples (Mt 6:12). This activity may take place in earthly life, and yet, in sinful failure, often does not. In light of this common failure, perhaps we could imagine the life of the blessed dead in the activity of offering forgiveness eschatologically. The forgiving actions of the blessed dead imitate Jesus' unwillingness to reproach those who have done him harm as the beginning of real forgiveness and also the third embodied activity of the resurrected Jesus that we noted earlier, namely, his reconciliation of failure. The way Jesus forgives Peter makes it very clear that forgiveness is a task that blossoms in the conscious work of reconciliation. Jesus' efforts at reconciliation are powerful manifestations of grace, and through these actions Jesus allows Peter to renew their relationship, profess his love, and enter into his mission. The same may be said for the life of the blessed dead. To be a disciple of Jesus means that, even in the afterlife, the bonds of reconciliation that unite the communion of the saints must be forged in the work of forgiveness, made and remade in acts of love that grace those who forgive as much as those who are forgiven.

\section{BECOMING MOST ONESELF IN RESURRECTED LIFE}

Hans Frei's compelling interpretation of Jesus' resurrection helped us to understand what Jesus does in the afterlife, and in a way that embraces all his other eschatological actions. Jesus, he noted, becomes most himself in his resurrection. His very person, his character as demonstrated in his actions, is completed in the events of his resurrected life. We can conclude our essay by considering how this last, and most comprehensive, description of Jesus' deeds in the afterlife can serve as a paradigm for the life of the blessed dead.

Applying Frei's description of Jesus' resurrected life to the blessed dead immediately poses problems. Jesus, after all, led a sinless life, and so his resurrection is easily and consistently imaginable as his personal fulfillment. Indeed, Frei's very point is that careful readers of the Gospel find a remarkable continuity between who Jesus was in his earthly life and who he is in his afterlife. Any talk of the resurrected fulfillment of believers as an imitation of Jesus would need to acknowledge that this imitation, like any act of Christian discipleship, is always limited by the transcendence of Jesus' divine nature and the transcendence of his sinless humanity. If the blessed dead can be described as becoming who they most are in heavenly afterlife, then this becoming must be understood as a transformation brought about by God's grace. Resurrected life is nothing less than a miracle through which, faith holds, believers will become much more than who they were in life, and yet in a way that fulfills who they always were. In Paul's language, this transformation is a "new creation" in which the 
power of sin, "everything old," has passed away (2 Cor 5:17). The personal continuity of the blessed dead thankfully is not beholden to the standard set by Jesus. Their salvation, becoming who they most are, to some degree entails becoming who they were not-persons broken by their sin and the sin of others. This miraculous continuity, one that yet abides in spite of the personal burdens of sin, is largely the work of God's grace.

The Catholic argument of this essay, though, has proposed that who we become in resurrected life continues to transpire by grace and works, and has suggested that the resurrected actions of Jesus provide a model for discipleship even in the afterlife. For the blessed dead to continue to be who they are, they must act in character. But acting in character for the blessed dead, being who they truly are even as they are transformed by grace, requires their imitation of Jesus. This imitation remains a task, and even a challenge, precisely because the effects of sin linger in resurrected life. Like the wounds on Jesus' resurrected body, the effects of sin-both responsibility for it and its victimizing consequences-continue to inform personal identity in resurrected life. This is not to say that sin is still a possibility for the blessed dead. The possibility of sin would be a meaningless notion apart from its actuality, and to allow for the actuality of sin in the life of the blessed dead would be to concede that redemption could be undone. Rather, the transformation that makes the blessed dead who they most are is real and meaningful only to the extent that its gracefulness neither annuls the effects of sin nor reduces the redeemed to a less than personal existence. The effects of sin mark the identity of the person who perpetrated and suffered them, just as much as do the salutary effects of virtue. And to be a person shaped in identity by both good and evil presupposes rational and willful agency, not only in this life but also in the life to come. For the blessed dead to be themselves they must continue to act, and act in ways that communicate their character as the saints. To be most fully themselves, they must exercise saintly character toward the heritage of $\sin$ as well as toward the heritage of grace.

We can imagine this moral activity in the most distant reaches of eternity continuing to take place long after the final judgment has been passed on all and the number of the saints in heaven is complete. To do so would assume that the saints are most themselves not only in blissful repose before the glory of the beatific vision but also in the virtuous work of forgiveness that is as never-ending as the effects of sin in resurrected life. Our appreciation of the communion of the saints increases if we imagine the blessed dead presently engaged in the same graceful activity of reconciliation, both among themselves and toward those in earthly life where the actuality of sin ever threatens the solidarity of the saintly community. Our appreciation of the communion of the saints increases even more if we envision this saintly activity not only as the ardent moral behavior of the 
blessed dead but also as the task of those in earthly life who aspire to become most themselves in resurrected life. Just as we imagined that the reconciling activity of the blessed dead extends throughout heaven and earth, so too should we imagine the same scope of Christian discipleship for those in earthly life. While there are differences in the communion of the saints, there finally is no difference among all the saints, living and dead, in their responsibility to imitate Jesus in all their natural and supernatural relationships.

It may seem as though the description of the blessed dead offered in these pages is more an account of life in purgatory than of heavenly life. Perhaps this is so because we are unused to imagining the effects of sin lasting in heavenly life, and inclined to think that the blessed dead so share in the eternal life of God that, like the divine nature, they are impervious to the sort of change that the exercise of character demands. For the blessed dead to be themselves, though, they must continue to be persons shaped by the history of sin. For the blessed dead to be most fully themselves, they must continue to act in the afterlife in imitation of Jesus' own resurrected life in ways that defeat the burden of sin that they both made and suffered. The negotiation of sin is certainly the business of the dead in purgatory. But it is important to imagine heavenly life continuing that task in its own way, for a lesser conception risks the loss of our selves in all their integrity. ${ }^{37}$

The images of resurrected life presented here do not aspire to literalism, and they certainly do not claim to be exhaustive. They remain interpretable acts of the imagination and stand in the company of many others that might be warranted by Scripture and tradition. Theology should not shrink from the task of thickly describing the eschata, a practice valued highly throughout Christian history. In spite of the modern dismissal of such activity as pious caprice, imagining eschatologically can be a serious measure of faith and hope. However modest our results must be, they can be an effective rejoinder to the mystical silence that now so easily claims authenticity as the most meaningful theology of the afterlife. Our modest results have proposed that one answer to our interrogative title is that we may hope to be busy in eternity at the work of redemption, whose gift we have received. ${ }^{38}$

${ }^{37}$ Bradford Hinze has written convincingly of our theological reluctance to speak of sinful dimensions of the communion of the saints, and of the need to do so in order to acknowledge the reality of human fallenness, which is not annulled by saintly virtue. Hinze makes this point ecclesiologically, with regard to the sin of the church. I propose here that his important insight applies eschatologically as well. See Bradford E. Hinze, "Ecclesial Repentance and the Demands of Dialogue," Theological Studies 61 (2000) 232-33.

${ }^{38}$ I am grateful to John Jones, Paul Lakeland, and Randy Sachs, S.J., who offered helpful criticism of this essay in draft. 